\title{
PENGARUH NASI PUTIH BARU MATANG DAN NASI PUTIH KEMARIN (TERETROGRADASI) TERHADAP KADAR GLUKOSA DARAH POSTPRANDIAL PADA SUBJEK WANITA PRA DIABETES
}

\author{
Afiska Prima Dewi, Muflihah Isnawati*) \\ Program Studi Ilmu Gizi Fakultas Kedokteran Universitas Diponegoro \\ Jl.Dr.Sutomo No.18, Semarang, Telp (024) 8453708, Email : gizifk@undip.ac.id
}

\begin{abstract}
Background : Diabetes mellitus is a metabolic disease with characteristic hyperglycemia. Factors that increase the risk of diabetes mellitus is unhealth eating patterns such as diet high in glycemic index. One type of food with high glycemic index is rice. However, storing and decreasing temperature of rice can undergo a process of retrogradation that rice resistant starch levels higher compared to fresh cooked white rice (still gelatinizated). Consuming food with high levels of resistant starch can decrease blood glucose levels.

Objective : The aim of this study was to know the effect of fresh cooked white rice and 24-hour retrogradation white rice on postprandial blood glucose levels $(1 / 2,1$, and 2 hours) on the subject of pre diabetes women.

Method : This experimental study used pre-post controlled grup design and pre diabetes women beings as subject of study. Amount of sampel were 18 people that divided into 2 groups : control group (got fresh cooked white rice) and treatment group (got 24-hour-retrogradation white rice). Blood glucose levels were measured by using glucometer test. Independent sample t-test dan uji Mann-Whitney were used to analyze the difference of blood glucose levels in both groups.

Results : The average of $1 / 2,1$, and 2 hour postprandial blood glucose leves in group 1 was 145,6; 138,1; and 124,4 $\mathrm{mg} / \mathrm{dl}$ and group 2 was 149,63; 121,13; dan 118,75 mg/dl. Statistic test showed that no significant difference in both groups $(p>0,05)$.
\end{abstract}

Conclusion : The rise of average postprandial blood glucose after consuming 24-h-retrogradation white rice wasn't different after consuming fresh cooked white rice.

Key words : fresh cooked white rice, 24-hour-retrogradation white rice, resistant starch, retrogradation, postprandial blood glucose levels

\begin{abstract}
ABSTRAK
Latar Belakang : Diabetes mellitus merupakan suatu penyakit metabolik dengan karakteristik hiperglikemia. Faktor yang meningkatkan risiko diabetes mellitus adalah pola makan yang tidak sehat, seperti diet tinggi indeks glikemik. Salah satu jenis pangan berindeks glikemik tinggi adalah nasi. Namun, nasi yang disimpan dan mengalami penurunan suhu dapat mengalami proses retrogradasi sehingga nasi memiliki kadar pati resisten yang lebih tinggi dibandingkan dengan nasi yang baru matang (masih tergelatinisasi). Konsumsi makanan dengan kadar pati resisten yang tinggi dapat menurunkan kenaikan kadar glukosa darah.

Tujuan : Tujuan penelitian ini untuk mengetahui pengaruh diet nasi putih baru matang dan nasi putih kemarin (teretrogradasi) terhadap kadar glukosa darah postprandial (1/2, 1, dan 2 jam) pada subjek wanita pra diabetes.

Metode : Penelitian ini adalah penelitian experimental dengan rancangan pre-post controlled grup design yang menggunakan wanita pra diabetes sebagai subjek penelitian. Total sampel 18 orang yang dibagi menjadi 2 kelompok yaitu kelompok kontrol (mendapat nasi putih baru matang) dan kelompok perlakuan (mendapat nasi putih kemarin). Metode pengukuran kadar glukosa darah adalah dengan menggunakan alat glucometer test. Independent sample t-test dan uji Mann-Whitney digunakan untuk menganalisis perbedaan kadar glukosa darah pada kedua kelompok.

Hasil : Rerata kadar glukosa darah 1/2, 1, dan 2 postprandial pada kelompok 1 sebesar 145,6; 138,1; dan 124,4 mg/dl dan kelompok 2 sebesar 149,63; 121,13; dan 118,75 mg/dl. Hasil uji statistik menunjukkan tidak ada perbedaan yang bermakna antara kedua kelompok ( $p>0,05)$.
\end{abstract}

Simpulan : Kenaikan rerata glukosa darah postprandial setelah konsumsi nasi putih kemarin tidak berbeda dengan kenaikan setelah konsumsi nasi putih baru matang.

Kata kunci : nasi putih baru matang, nasi putih kemarin, pati resisten, retrogradasi, kadar glukosa darah postprandial

\section{PENDAHULUAN}

Diabetes mellitus (DM) merupakan suatu penyakit metabolik dengan karakteristik hiperglikemia (glukosa darah tinggi) yang terjadi karena kelainan sekresi insulin, resistensi insulin, atau keduanya. Diabetes mellitus dibagi menjadi 2 
jenis, yaitu diabetes tipe 1 dan tipe 2. Diabetes tipe 1 terjadi karena sel beta pankreas yang memproduksi insulin dalam tubuh tidak berfungsi dan hanya memproduksi sedikit atau tidak sama sekali insulin. Sedangkan diabetes tipe 2 terjadi akibat kombinasi dari kecacatan produksi insulin dan resistensi insulin di membrane sel tubuh. Diabetes tipe 2 merupakan jenis diabetes yang paling banyak dijumpai, dengan jumlah penderita lebih dari $90 \%$ dari total penderita diabetes. ${ }^{1}$ Apabila tidak diatasi, penyakit diabetes mellitus dapat menimbulkan berbagai komplikasi kronis pada tubuh, baik komplikasi pada mikroangiopati maupun makroangiopati. Komplikasi mikroangiopati kronis dapat menimbulkan kebutaan, gagal ginjal, dan kerusakan saraf, sedangkan komplikasi makroangiopati dapat menimbulkan aterosklerosis, stroke, jantung koroner, dan penyakit pembuluh darah lain. ${ }^{2}$

Prevalensi penderita diabetes di Indonesia cukup tinggi dan cenderung mengalami peningkatan setiap tahunnya. Dari berbagai penelitian, prevalensi diabetes di Indonesia mencapai $1,5-2,3 \%$ pada penduduk usia lebih dari 15 tahun. Menurut data WHO, Indonesia menempati urutan ke-4 terbesar di dunia dalam jumlah penderita diabetes mellitus. ${ }^{3}$ Pada tahun 2011, jumlah penderita diabetes di kota Semarang mencapai 59.877 orang dengan jumlah penderita diabetes tipe 1 sebesar 14.326 orang dan jumlah penderita diabetes tipe 2 sebesar 45.551 orang. ${ }^{4}$

Pra diabetes merupakan kondisi dimana toleransi glukosa terganggu. Pra diabetes ditandai oleh kadar glukosa darah tinggi, namun belum termasuk dalam batas klasifikasi diabetes. Kadar glukosa darah puasa pra diabetes yaitu 100-125 $\mathrm{mg} / \mathrm{dl}$, sedangkan diabetes mellitus $\geq 126 \mathrm{mg} / \mathrm{dl}$. Apabila tidak diatasi, kondisi pra diabetes dapat berubah menjadi diabetes mellitus. Setelah 5-10 tahun, 1/3 populasi pra diabetes berkembang menjadi diabetes, 1/3 tetap pra diabetes, dan 1/3 lainnya kembali normal. Kondisi pra diabetes sering berkaitan dengan resisten insulin. Pra diabetes dapat diatasi dengan perubahan pola makan menjadi pola makan yang sehat sehingga kecenderungan menjadi diabetes mellitus dapat dicegah. ${ }^{1}$

Faktor yang meningkatkan risiko diabetes mellitus maupun pra diabetes adalah pola makan yang tidak sehat, seperti diet tinggi indeks glikemik dan tinggi lemak. ${ }^{5}$ Salah satu jenis pangan berindeks glikemik tinggi yang umum dikonsumsi setiap hari oleh masyarakat Indonesia adalah nasi. Penelitian pada tahun 2012 menunjukkan bahwa konsumsi nasi putih yang tinggi berhubungan secara signifikan terhadap peningkatan risiko diabetes tipe 2 dimana setiap kenaikan porsi asupan nasi putih per hari risiko relatif diabetes mellitus tipe 2 adalah 1,11 ( $P$ linear $<0,001) .{ }^{6}$ Penelitian lain pada tahun 2011 terhadap konsumsi nasi putih menunjukkan konsumsi nasi putih berkolerasi positif pada tekanan darah, trigliserida, dan glukosa darah puasa, serta berkolerasi negatif pada HDL kolesterol. ${ }^{7}$

Di Indonesia, terdapat sugesti terhadap nasi putih kemarin (sego wadang) dimana menurut penderita diabetes mellitus maupun pra diabetes nasi kemarin dapat membantu mengontrol kadar glukosa darah. Secara ilmiah hal tersebut dapat dijelaskan sebagai akibat perubahan suhu yang kemudian mempengaruhi stuktur pati pada nasi sehingga pati resisten yang terkandung nasi menjadi meningkat kadarnya. ${ }^{8}$

Pati resisten (starch resisten) adalah pati yang tidak tercerna dengan baik dalam usus halus tapi terfermentasi pada usus besar oleh mikroflora. Pati resisten terdapat dalam berbagai bentuk dan tingkatan stabilitas. Pati yang teretrogradasi, khususnya amilosa, adalah jenis pati resisten yang paling stabil. Hal ini karena rantai amilosa yang lurus mudah tergradasi dan ketika rantai amilosa bergabung kembali (retrogradasi) akan membentuk sebuah polimer yang kompak dan sulit untuk dihidrolisis oleh enzim pencernaan. ${ }^{9,10}$ Pati resisten dalam bahan makanan dipengaruhi oleh beberapa faktor seperti proses pengolahan serta adanya senyawa lain. Pada proses pengolahan, proses gelatinisasi dapat meningkatkan kelarutan dan kecernaan pati sehingga dapat menurunkan kandungan pati resisten bahan tersebut. Namun, proses pemanasan dan pendinginan kembali dapat menyebabkan terbentuknya pati teretrogradasi yang bersifat tidak larut. ${ }^{11}$

Mengkonsumsi makanan dengan kadar pati resisten yang tinggi dapat mengontrol kenaikan kadar glukosa darah akibat pelepasan glukosa yang lambat (5-7 jam). Hal tersebut dapat menurunkan respon insulin tubuh dan menormalkan kembali kadar glukosa darah. ${ }^{13,14}$ Penelitian tahun 2007 menunjukkan bahwa mengonsumsi pati resistent dapat secara efektif memperbaiki resistensi insulin pada pasien diabetes tipe $2 .{ }^{15}$ Penelitian tahun 2005, 2006, dan 2009 menunjukkan bahwa mengonsumsi makanan yang mengandung pati resisten dapat menurunkan kadar glukosa darah postprandial dan meningkatkan produksi insulin. ${ }^{16,17,18}$ 
Nasi yang mengalami penurunan suhu dalam waktu lama akan mengalami proses retrogradasi sehingga nasi memiliki kadar pati resisten yang lebih tinggi dibandingkan dengan nasi yang baru matang. Proses retrogradasi akan maksimal pada suhu $4^{\circ} \mathrm{C}$ dan disimpan selama 24 jam. Kadar pati resisten pada nasi putih kemarin (teretrogradasi) yaitu $13,9 \pm 0,98$, sedangkan kadar pati resisten pada nasi yang baru matang yaitu $9,1 \pm 1,02 .^{8}$ Penelitian tahun 2003 (in vitro) menunjukkan nasi yang disimpan pada suhu $4^{\circ} \mathrm{C}$ selama 24 jam memiliki Glycemic Index (GI) dan tingkat kecernaan pati yang lebih rendah dibandingkan nasi yang baru matang (tidak mengalami retrogradasi). ${ }^{19}$

Berdasarkan informasi tersebut, peneliti mencoba untuk meneliti efek dari nasi putih baru matang dengan nasi putih kemarin terhadap kadar glukosa darah $1 / 2,1$, dan 2 jam postprandial. Pengukuran kadar glukosa darah $1 / 2,1$, dan 2 jam postprandial dipilih dengan alasan untuk mengetahui respon glukosa darah sampel terhadap diet yang diberikan dan untuk membandingkan pengaruh antara diet nasi putih baru matang dengan nasi putih kemarin terhadap glukosa darah.

Subjek dalam penelitian ini adalah manusia (wanita) dengan kondisi pra diabetes. Wanita dipilih sebagai subjek penelitian dikarenakan kejadian diabetes mellitus tipe 2 dan gangguan toleransi glukosa terjadi lebih banyak dibandingkan pria. ${ }^{20}$ Tujuan penelitian ini untuk mengetahui pengaruh diet nasi putih baru matang dan nasi putih kemarin terhadap kadar glukosa darah postprandial $(1 / 2,1$, dan 2 jam $)$ pada subjek wanita pra diabetes.

\section{METODE}

Penelitian ini adalah penelitian
experimental dengan rancangan pre-post controlled grup design yang menggunakan manusia sebagai subjek penelitian.

Populasi target penelitian ini adalah wanita pra diabetes di Kota Semarang. Sedangkan populasi terjangkau pada penelitian adalah wanita pra diabetes anggota klub diabetes RS Panti Wilasa Citarum, anggota klub diabetes dan klub lansia RS Telogorejo, serta warga RW 7 Kelurahan Randusari.

Sampel diambil menggunakan metode consecutive sampling dari populasi terjangkau yang memenuhi kriteria antara lain berjenis kelamin wanita, usia 50-75 tahun, IMT (Indeks Massa Tubuh) $18,5-25 \mathrm{~kg} / \mathrm{m}^{2}$, tidak dalam kondisi sakit atau dalam perawatan dokter terkait penyakit kronis, serta kadar glukosa darah puasa (GDP) 100-125 mg/dl. Besar sampel dihitung menggunakan rumus uji beda rata-rata 2 kelompok independen dengan simpang baku kedua kelompok sebesar 3,58 (didapatkan dari penelitian sebelumnya) ${ }^{18}$, perbedaan klinis yang diinginkan oleh peneliti sebesar $5 \mathrm{mg} / \mathrm{dl}$, tingkat kemaknaan yang ditetapkan peneliti sebesar $95 \%$, serta power yang ditetapkan peneliti sebesar $80 \%$ sehingga didapatkan sampel sebanyak 8 orang untuk tiap kelompok. Untuk menghindari terjadinya drop out maka jumlah sampel ditambah $20 \%$ tiap kelompok sehingga menjadi 10 orang tiap kelompok.

Proses pengambilan sampel dilakukan dengan menawarkan kesediaan menjadi sampel penelitian pada populasi saat dilakukan sosialisasi penelitian. Jika bersedia, subjek diminta untuk menandatangani informed consent. Selanjutnya dilakukan proses wawancara serta pengukuran berat badan dan tinggi badan untuk mengetahui apakah subjek memenuhi kriteria inklusi usia, IMT, dan kondisi kesehatan. Subjek kemudian dimintai untuk puasa selama 8 jam sebelum datang pada hari yang telah ditentukan untuk dilakukan penelitian. Setelah puasa selama 8 jam kadar glukosa darah puasa subjek diukur untuk mengetahui apakah kadar glukosa darah puasa subjek memenuhi kriteria inklusi.

Subjek yang memenuhi seluruh kriteria inklusi dan dinyatakan sebagai sampel penelitian kemudian dibagi menjadi dua kelompok yaitu kelompok kontrol (mendapat nasi putih baru matang) dan kelompok perlakuan (mendapat nasi putih kemarin). Setelah sampel mengonsumsi nasi, $1 / 2,1$, dan 2 jam sesudahnya kadar glukosa darah sampel diukur. Kriteria eksklusi pada penelitan yaitu sampel mengundurkan diri, sampel tidak taat pada prosedur penelitian, meninggal dunia, serta jumlah nasi yang dikonsumsi $<80 \%$. Beras yang digunakan yaitu jenis $\mathrm{C} 4$.

Variabel bebas dalam penelitian ini yaitu nasi putih baru matang dan nasi putih kemarin yang diberikan dengan jumlah pemberiang masingmasing $125 \mathrm{~g}$ ditambah lauk telur rebus bumbu balado 1 butir $(60 \mathrm{~g})$. Sedangkan variabel terikat pada penelitian ini yaitu kadar glukosa $1 / 2,1$, dan 2 jam darah postprandial.

Data primer berupa hasil perhitungan IMT (dari pengukuran TB dan $\mathrm{BB}$ ), data umum dan kondisi kesehatan (dari hasil wawancara), serta kadar glukosa darah puasa dan kadar glukosa darah $1 / 2,1$, dan 2 jam postprandial dari hasil pengukuran menggunakan alat glukometer. 
Data yang diperoleh kemudian diolah dengan program computer SPSS 17 dan diuji normalitas menggunakan uji Kolmogorov-Smirnov. Hasil pengujian data pada $1 / 2$ dan 2 jam, data berdistribusi normal sehingga data lalu diuji beda dengan menggunakan uji independent t-test. Sedangkan hasil pengujian pada 1 jam data berdistribusi tidak normal sehingga data diuji dengan uji non parametrik Mann Whitney. Nilai kemaknaan yang digunakan pada penelitian ini yaitu 0,05 .

\section{HASIL PENELITIAN}

Karakteristik sampel
Pada akhir penelitian, tiga orang sampel pada kelompok pertama drop out dan lima orang sampel pada kelompok kedua drop out sehingga jumlah akhir sampel adalah 18 orang terdiri dari 10 orang pada kelompok pertama dan 8 orang pada kelompok kedua. Rerata usia sampel adalah 55,61 tahun dengan rentang usia 50 sampai 68 tahun. Sebagian besar sampel berada pada kelompok usia 50 sampai 55 tahun $(55,5 \%)$.

Keadaan sampel pada awal penelitian

Keadaan awal sampel antara kedua kelompok perlu dibandingkan untuk mengetahui homogenitas sampel sebelum diberi perlakuan.

Tabel 1. Keadaan sampel pada awal penelitian

\begin{tabular}{lcccccc}
\hline \multirow{2}{*}{$\begin{array}{c}\text { Jenis } \\
\text { Pengukuran }\end{array}$} & \multicolumn{2}{c}{ Kelompok 1 $(\mathrm{n}=10)$} & \multicolumn{2}{c}{ Kelompok 2 $(\mathrm{n}=8)$} & & \\
\cline { 2 - 5 } & Rerata & SD & Rerata & SD & t & $p$ \\
\hline Usia (tahun) & 56.60 & & 54.38 & 6.116 & 0.761 & 0.458 \\
IMT $\left(\mathrm{kg} / \mathrm{m}^{2}\right)$ & 22.89 & 6.204 & 23.987 & 1.579 & & 0.286 \\
$\mathrm{~b}$ & 107.60 & 1.994 & 103.25 & 2.121 & 1.882 & 0.860 \\
GDP $(\mathrm{mg} / \mathrm{dl}){ }^{\mathrm{a}}$ & & 6.915 & & & & \\
\hline
\end{tabular}

Keterangan : IMT (Indeks Massa Tubuh). GDP(Glukosa Darah Puasa)

${ }^{a}$ Independent Samples T-test pada $\alpha=0.05$

${ }^{b}$ Non parametrik Mann Whitney pada $\alpha=0.05$

Pada tabel 1 terlihat bahwa rerata usia dan kadar glukosa darah puasa pada kelompok 1 lebih tinggi daripada kelompok 2, sedangkan untuk rerata IMT pada kelompok 2 lebih tinggi daripada kelompok 1. Namun, secara statistik tidak ada beda usia, IMT, dan glukosa darah puasa pada kedua kelompok $(p>0.05)$.

\section{Asupan nasi sampel selama penelitian}

Asupan nasi sampel selama penelitian dipantau dengan menimbang sisa makanan (nasi) sampel. Adapun rerata asupan nasi sampel selama penelitian dapat dilihat pada tabel 2 .

Tabel 2. Rerata persen asupan nasi selama penelitian

\begin{tabular}{cccccccc}
\hline & \multicolumn{2}{l}{ Kelompok 1 $(\mathrm{n}=10)$} & \multicolumn{2}{c}{ Kelompok 2 $(\mathrm{n}=8)$} & & \\
& Rerata & $\mathrm{SD}$ & Rerata & $\mathrm{SD}$ & $\mathrm{t}$ & $p^{\mathrm{a}}$ \\
\hline Asupan nasi (\%) & 100.00 & 0.000 & 93.50 & 9.304 & 1.976 & 0.08 \\
& & & & & & 9 \\
\hline
\end{tabular}

Keterangan : ${ }^{a}$ Independent Samples T-test pada $\alpha=0.05$

Pada tabel 2 tampak bahwa rerata persen asupan nasi pada kelompok 1 (nasi putih baru matang) adalah 100.00. sedangkan rerata persen asupan nasi pada kelompok 2 (nasi putih kemarin) adalah 93.50. Secara statistik tidak ada beda rerata asupan makan selama penelitian pada kedua kelompok $(p>0.05)$.
Pengaruh konsumsi nasi putih baru matang dan nasi putih kemarin terhadap kadar glukosa darah postprandial

Pengaruh konsumsi nasi baru matang dan nasi kemarin terhadap kadar glukosa darah 1/2. 1 . dan 2 jam postprandial dapat dilihat pada tabel 3 dan grafik 1.

Tabel 3. Kadar glukosa darah sebelum dan sesudah intervensi

\begin{tabular}{lccc}
\hline $\begin{array}{l}\text { Kelompok } \\
\text { perlakuan }\end{array}$ & $\begin{array}{c}\text { Kadar glukosa } \\
\text { darah puasa }\end{array}$ & \multicolumn{2}{c}{ Kadar glukosa darah setelah makan $^{1 / 2 \text { jam }^{\mathrm{a}}}$} \\
\hline
\end{tabular}




\begin{tabular}{lcccccccc}
\hline & rerata & SD & rerata & SD & rerata & SD & rerata & SD \\
\hline Kel. 1 $(\mathrm{n}$ & & 6.91 & 145.6 & 12.79 & & & & \\
$=10)$ & 107.60 & 5 & 0 & 9 & 138.10 & 23.886 & 124.40 & 27.423 \\
Kel. 2 $(\mathrm{n}=8)$ & 103.25 & 2.12 & 149.6 & 12.17 & 121.13 & 18.689 & 118.75 & 14.646 \\
& & 1 & 3 & 7 & & & & \\
& $p$ & & 0.508 & 0.110 & 0.625 \\
\hline
\end{tabular}

${ }^{a}$ Independent Samples T-test pada $\alpha=0.05$

${ }^{b}$ Non parametrik Mann Whitney pada $\alpha=0.05$

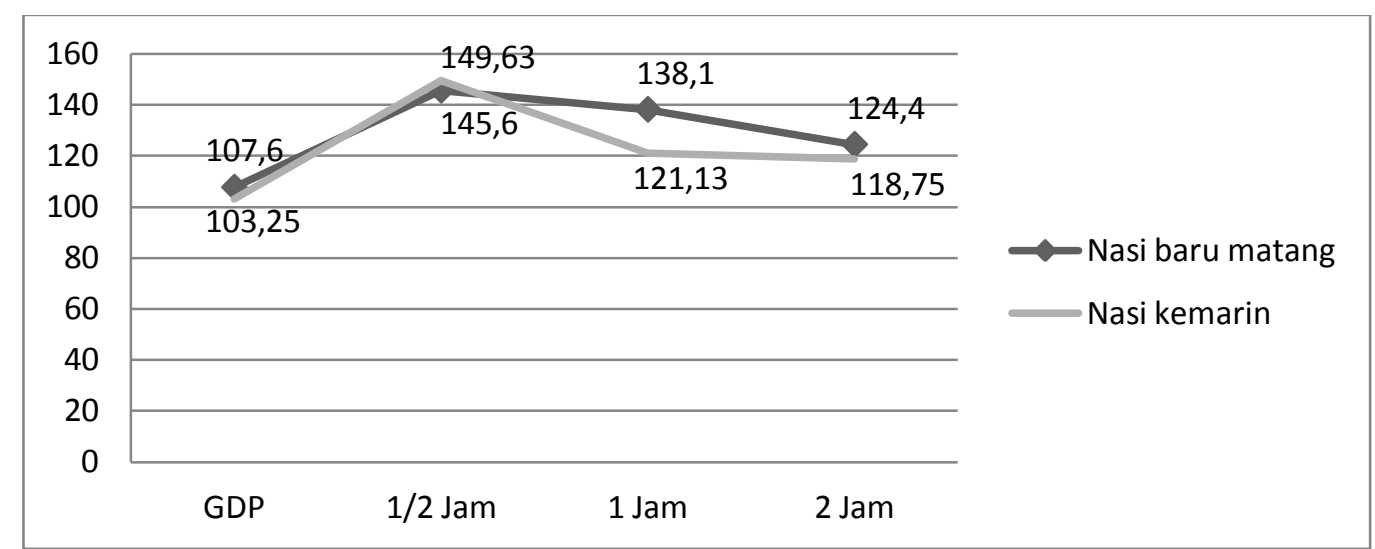

Gambar 1. Grafik perbandingan pengaruh nasi baru matang dan nasi kemarin

Berdasarkan tabel 3 dan gambar 1 terlihat bahwa kadar glukosa darah pada kelompok 2 lebih tinggi daripada kelompok 1 saat $1 / 2$ jam setelah makan $(\Delta 4,03 \mathrm{mg} / \mathrm{dl})$, namun kelompok 2 lebih rendah daripada kelompok 1 saat 1 jam setelah makan $(\Delta 16,97 \mathrm{mg} / \mathrm{dl})$ dan 2 jam setelah makan $(\Delta$ $5,65 \mathrm{mg} / \mathrm{dl})$. Walaupun begitu, secara statistik menunjukkan tidak ada beda antara kedua kelompok $(p>0,05)$.

\section{PEMBAHASAN}

Nasi yang mengalami penurunan suhu dalam waktu lama akan mengalami proses retrogradasi sehingga nasi memiliki kadar pati resisten yang lebih tinggi dibandingkan dengan nasi yang baru matang (masih tergelatinisasi). Hal tersebut disebabkan karena pemanasan dan pendinginan kembali dapat menyebabkan terbentuknya pati teretrogradasi yang bersifat tidak larut. Pati resisten paling besar terbentuk dari retrogradasi amilosa, meski amilopektin juga dapat teretrogradasi akan tetapi amilopektin memerlukan waktu yang lama untuk mengalami retrogradasi. Hal ini karena rantai amilosa yang lurus mudah tergradasi dan ketika rantai amilosa bergabung kembali (retrogradasi) akan membentuk sebuah polimer yang kompak dan sulit untuk dihidrolisis oleh enzim pencernaan. ${ }^{9,10}$ Penelitian sebelumnya menunjukkan kadar pati resisten pada nasi yang teretrogradasi yaitu $13,9 \pm 0,98$, sedangkan kadar pati resisten pada nasi yang baru matang yaitu $9,1 \pm 1,02{ }^{8}$ Proses retrogradasi lebih terjadi pada suhu refrigerator (kulkas) daripada suhu ruang. ${ }^{21}$ Berdasarkan penelitian sebelumnya, proses retrogradasi akan maksimal pada suhu $4^{\circ} \mathrm{C}$ dan disimpan selama 24 jam. $^{8}$ Penelitian tahun 2003 (in vitro) menunjukkan nasi putih kemarin yang disimpan pada suhu $4^{\circ} \mathrm{C}$ selama 24 jam memiliki Glycemic Index (GI) dan tingkat kecernaan pati yang lebih rendah dibandingkan nasi putih yang baru matang (tidak mengalami retrogradasi). ${ }^{19}$ Beberapa penelitian sebelumnya menunjukkan bahwa pati resisten dapat menurunkan kadar glukosa darah postprandial dan meningkatkan produksi insulin ${ }^{16,17,18}$ serta memperbaiki resistensi insulin pada pasien diabetes tipe $2 .{ }^{15}$

Nasi kemarin pada penelitian ini dibuat dengan cara menyimpan nasi pada suhu $4^{\circ} \mathrm{C}$ di refrigerator selama 24 jam. Selama di refrigerator nasi disimpan pada wadah tertutup. Hal ini dilakukan untuk mencegah adanya kontaminasi bakteri pada nasi kemarin. Setelah disimpan selama 24 jam di refrigerator, nasi kemudian dihangatkan kembali sebelum disajikan kepada sampel. Hal ini dilakukan untuk meningkatkan daya terima nasi kemarin sebab nasi kemarin yang 
baru keluar dari refrigerator berkondisi rigid (keras) dan dingin sehingga dapat menurunkan daya terima nasi.

Ada beberapa faktor yang dapat mempengaruhi terbentuknya pati resisten. Faktorfaktor tersebut yaitu sifat alami pati (struktur granula, kristalinitas pati, rasio amilosa dan amilopektin, retrogradasi amilosa, panjang rantai amilosa, serta linearisasi amilopektin), suhu, kelembapan, dan interaksi pati dengan komponen lain (protein, lemak, serat, inhibitor enzim). ${ }^{22}$

Proses retrogradasi lebih mudah terjadi pada pati yang mengandung amilosa tinggi. Hal ini dikarenakan rantai amilosa yang lurus mudah tergradasi dan ketika rantai amilosa bergabung kembali (retrogradasi) akan membentuk sebuah polimer yang kompak dan sulit dihidrolisis oleh enzim pencernaan., ${ }^{9,10}$ Penelitian tahun 2011 menunjukkan bahwa peningkatan kadar amilosa pada serealia meningkatkan kadar pati resisten dalam bahan makanan tersebut ketika telah mengalami retrogradasi. Kadar amilosa pati beras yang digunakan (jenis $\mathrm{C} 4$ ) tidak begitu tinggi dibandingkan dengan kadar amilosa serealia pada penelitian sebelumnya yang memberikan pengaruh yang signifikan terhadap kadar glukosa darah. Beras jenis C4 memiliki kadar amilosa 21-23\% dengan kadar pati resisten sebesar 13,9\% (setelah teretrogradasi), sedangkan pada penelitian 2011 kadar amilosa yang terkandung sebanyak 38\% memiliki pati resisten sebesar $19 \%$. $^{23}$

Kandungan air pada pati berpengaruh pada pati resisten yang dihasilkan. Kadar pati resisten dapat maksimal ketika rasio pati dan air sebesar 1 : 3,5. ${ }^{22}$ Pada penelitian ini, setelah proses pemasakan nasi disimpan pada wadah tertutup pada suhu $4^{\circ} \mathrm{C}$ di refrigerator selama 24 jam. Kesalahan mungkin terjadi pada proses ini sebab penyimpanan pada suhu rendah dengan menggunakan wadah tertutup mempengaruhi sirkulasi udara, kelembapan, dan kadar air pada pati beras. Dengan penggunaan wadah tertutup, uap yang berasal dari nasi yang matang terperangkap sehingga kadar air meningkat. Selain itu, sirkulasi udara tertutup juga membuat penghantaran panas bahan pangan dengan dingin suhu lingkungan (refrigerator) dan penguapan air tidak maksimal. ${ }^{24}$

Pada penelitian ini, kelompok yang mendapat nasi putih kemarin saat $1 / 2$ jam postprandial rerata kadar glukosa darahnya lebih tinggi dibandingkan rerata kadar glukosa darah kelompok yang mendapatkan nasi putih baru matang. Selisih nilai kedua kelompok yaitu 4,03 $\mathrm{mg} / \mathrm{dl}$ dengan hasil uji statistik menunjukkan tidak ada beda antara kedua kelompok. Walaupun hasil uji statistik menunjukkan tidak ada beda, namun terdapat keanehan dimana rerata kelompok yang mendapat nasi putih kemarin justru lebih tinggi daripada kelompok nasi putih baru matang. Hal ini bertentangan dengan teori dimana makanan berindeks glikemik rendah seharusnya memiliki puncak kenaikan glukosa yang lebih rendah daripada makanan berindek glikemik tinggi. Saat proses penyimpanan nasi putih kemarin di refrigenerator, nasi putih kemarin disimpan dengan metode yang tidak benar sehingga kadar air dan kelembapan menjadi tidak sesuai. Hal itu mengakibatkan proses retrogradasi dan pati resisten yang terbentuk tidak maksimal. Selain itu, pada $1 / 2$ jam setelah makan pati baru sebagian tercerna sehingga sebagian pati resisten belum menunjukkan efek positif. Pemanasan kembali setelah pendinginan refrigerator tidak mempengaruhi kandungan pati resisten yang telah terbentuk. Hal ini karena pemanasan dan pendinginan berulang justru dapat meningkatkan kadar pati resisten. ${ }^{25}$

Kelompok yang mendapat perlakuan nasi putih kemarin saat 1 dan 2 jam postprandial rerata kadar glukosa darahnya lebih rendah dibandingkan rerata kadar glukosa darah kelompok yang mendapatkan nasi putih baru matang. Selisih nilai kedua kelompok yaitu $16,97 \mathrm{mg} / \mathrm{dl}$ pada saat 1 jam dan $5,65 \mathrm{mg} / \mathrm{dl}$ pada 2 jam dengan hasil uji statistik menunjukkan tidak ada beda antara kedua kelompok. Walaupun hasil uji statistik menunjukkan tidak ada beda, namun selisih perbedaan yang terjadi cukup besar terutama pada saat 1 jam postprandial. Berbeda dengan $1 / 2$ jam postprandial dimana kelompok perlakuan (nasi putih kemarin) justru lebih tinggi daripada kelompok kontrol (nasi putih baru matang), di 1 jam postprandial yang terjadi justru sebaliknya dan penurunan rerata glukosa darah dari $1 / 2$ ke 1 jam postprandial terjadi cukup drastis yaitu sebesar $28,5 \mathrm{mg} / \mathrm{dl}$. Sedangkan penurunan rerata glukosa darah dari 1 jam ke 2 jam postprandial sebesar 2,38 $\mathrm{mg} / \mathrm{dl}$.

Penurunan rerata kadar glukosa darah mulai dari 1 jam postprandial dapat disebabkan oleh efek positif pati resisten yang terdapat pada nasi putih kemarin. Efek fisiologis pati resisten terhadap kadar glukosa darah dapat dijelaskan melalui dua mekanisme yaitu penghambatan aktivitas enzim $\alpha$-amilase di usus halus dan peningkatan produksi asam lemak rantai pendek, terutama asam propionat, oleh bakteri anaerob di usus besar. Pati resisten merupakan pati yang tidak 
dapat ter-hidrolisis oleh enzim pencernaan. Hal ini mempengaruhi kekentalan isi usus yang mengakibatkan terjadinya penurunan aktivitas $\alpha$ amilase sehingga memperlambat penyerapan glukosa. ${ }^{26}$ Selain itu, asam lemak rantai pendek jenis propionat yang dihasilkan dari fermentasi pati resisten di usus besar juga dapat menghambat kerja HMG CoA (3 hidroksi 3 metil glutaril koenzim A) reduktase sehingga sintesis kolesterol berkurang. Propionat juga dapat menghambat glukoneogenesis melalui konversi HMG CoA menjadi metilmalonil CoA dan suksinil CoA serta mereduksi asam lemak bebas tingkat plasma. Asam lemak bebas tingkat plasma yang tinggi dapat menurunkan utilisasi glukosa dan menyebabkan terjadinya resistensi insulin di jaringan adiposa. Kerja dari propionat tersebut menyebabkan terjadinya peningkatan sekresi insulin serta sensitivitas insulin di jaringan adiposa. ${ }^{12,26,27}$

Pada penelitian ini, ada salah satu sampel yang menunjukkan karakteristik glukosa darah yang berbeda dengan sampel lainnya. Sampel tersebut pada $1 / 2$ jam postprandial kadar glukosa darahnya $151 \mathrm{mg} / \mathrm{dl}$, kemudian 1 jam postprandial turun menjadi $89 \mathrm{mg} / \mathrm{dl}$, dan pada 2 jam postprandial naik menjadi $150 \mathrm{mg} / \mathrm{dl}$. Sampel diketahui masuk dalam kriteria pra diabetes dengan kadar glukosa darah puasa hasil pengukuran 106 $\mathrm{mg} / \mathrm{dl}$. Hal yang membuat kadar glukosa darah pada sampel ini berbeda yaitu penurunan di 1 jam postprandial diikuti dengan kenaikan pada 2 jam postprandial. Kenaikan pada 2 jam postprandial ini besarnya hampir sama dengan $1 / 2$ jam postprandial dimana $1 / 2$ jam postprandial merupakan puncak kenaikan glukosa. Hal ini dapat terjadi dimungkinkan karena adanya proses glukoneogenesis.Glukoneogenesis merupakan pemecahan lemak dan protein yang terjadi akibat peningkatan kebutuhan glukosa. Peningkatan kebutuhan glukosa ini terjadi akibat penurunan kadar glukosa darah yang cukup drastis dari $1 / 2$ ke 1 jam postprandial pada sampel ini. Penurunan yang cukup drastis ini dimungkinkan karena kondisi hiperinsulinemia.

\section{SIMPULAN DAN SARAN Simpulan}

Tidak ada perbedaan yang bermakna terhadap kadar glukosa darah 1/2, 1, dan 2 jam postprandial antara wanita pra diabetes yang mendapat nasi putih baru matang dengan wanita pra diabtes yang mendapat nasi putih kemarin.

Saran
1. Perlu adanya penelitian lebih lanjut mengenai pengaruh nasi kemarin dengan pendinginan pada suhu ruang.

2. Perlu adanya penelitian lebih lanjut mengenai pengaruh nasi kemarin dengan beragam jenis varietas beras terhadap kadar glukosa darah.

\section{UCAPAN TERIMA KASIH}

Puji syukur penulis panjatkan ke hadirat Allah SWT atas segala rahmat dan kemudahan yang telah diberikan-Nya. Ucapan terima kasih yang tak terhingga penulis ucapkan kepada orang tua dan keluarga, pembimbing, Ibu Muflihah Isnawati, DCN, MSc atas bimbingan materi, penguji yang memberi banyak masukan, segenap dosen Program Studi Ilmu Gizi Fakultas Kedokteran Universitas Diponegoro atas ilmu yang diberikan, anggota klub diabetes RS Panti Wilasa, anggota klub diabetes dan klub lansia RS Telogorejo, dan warga RW 7 Kelurahan Randusari yang telah bersedia menjadi subjek penelitian, serta semua pihak yang telah mendukung penyusunan karya tulis ilmiah ini.

\section{DAFTAR PUSTAKA}

1. Gustaviani R. Diagnosis dan Klasifikasi Diabetes Mellitus. Dalam : Sudoyo AW, Setiyohadi B, Alwi I, Simadibrata M, Setiati S. Buku Ajar Ilmu Penyakit Dalam. Edisi IV. Jilid III. Jakarta : Pusat Penerbitan Departemen Ilmu Penyakit Dalam FKUI, 2006. Hal (1879 - 81)

2. Sidartawan S, Reno G. Sindrome Metabolik. Dalam : Ilmu Penyakit Dalam. Jakarta : Pusat Penerbitan Ilmu Penyakit Dalam FK UI, 2006. Hal (1850-57)

3. WHO. Diabetes Mellitus. (online) Available from URL : $\quad$ http://www.who.int/ topics/diabetes_mellitus/en. Accessed November 19, 2012

4. Dinas Kesehatan Kota (DKK) Semarang. Kasus penyakit tidak menular di puskesmas dan rumah sakit di Kota Semarang Tahun 2011. Semarang : DKK

5. Slamet Suyono. Diabetes Melitus di Indonesia. Ilmu Penyakit Dalam.Jakarta : Pusat Penerbitan Ilmu Penyakit Dalam FK UI : 2006. Hal ( 1852 53)

6. Emily A Hu, An Pan, Vasanti Malik, Qi Sun. White Rice Consumption and Risk of Type 2 Diabetes : Meta-analysis and Systematic Review. BMJ 2012; 344:e1454: 10.1136/bmj.e1454

7. Josiemer Mattei, Frank B Hu, Hannia Campos. A higher ratio of beans to white rice is associated with lower cardiometabolic risk factors in Costa Rican adults. Am J Clin Nutr 2011;94:869-76 
8. Ae Wha Ha, Gwi Jung Han, Woo Kyoung Kim. Effect of retrograded rice on weight control, gut function, and lipid concentrations in rats. Nutrition Research and Practice (Nutr Res Pract) 2012;6(1):16-20

9. Maria Hodsagi. Recent results of investigations of resistant starches. (Thesis) Budapest : Department of Applied Biotechnology and Food Sciences, Budapest University of Technology and Economics, 2011

10. Keren Shamai, Havazelet Bianco-Peled, Eyal Shimoni. Polymorphism of resistant starch type III. Carbohydrate Polymers 54 (2003) 363-369

11. Elessandra da Rosa Zavareze, Shanise L. Mello El Halal, Diego G. de los Santos, Elizabete Helbig, Juliane Mascarenhas Pereira, Alvaro R. Guerra Dias. Resistant starch and thermal, morphological andtextural properties of heat-moisture treated ricestarches with high-, medium- and low-amylose content. Starch/Starke 2012, 64, 45-54

12. Todesco $\mathrm{T}$, Venketshwer R, Bosello O, Propionate lowers blood glucose and alters lipid metabolism in healthy subjects. Am J Clin Nutr 1991; 54: 560-5.

13. Mark D. Haub, Kelcie L. Hubach, Enas K. Altamimi, Sammy Ornelas, Paul A.Seib. Different Types of Resistant Starch Elicit Different Glucose Reponses in Humans. Journal of Nutrition and Metabolism. Volume 2010, Article ID 230501, doi:10.1155/2010/230501

14. M Denise Robertson, Alex S Bickerton, A Louise Dennis, Hubert Vidal. Insulin-sensitizing effects of dietary resistant starch and effects on skeletal muscle and adipose tissue metabolism. Am J Clin Nutr 2005;82:559-67.

15. Zhang W.Q., Wang H.W., Zhang Y.M., Yang Y.X.Effects of resistant starch on insulin resistance of type 2 diabetes mellitus patients. Zhonghua $\mathrm{Yu}$ Fang Yi Xue Za Zhi. 2007 Mar;41(2):101-4

16. Yuji Yamada, Sejo Hosoya, Shigeru Nishimura, Takashi Tanaka, Yoshitaka Kajimoto, Akira Nishimura, and Osami Kajimoto. Effect of Bread Containing Resistant Starch on Postprandial Blood Glucose Levels in Humans. Biosci. Biotechnol. Biochem., 69 (3), 559-566, 2005

17. Kay M. Nehall, Daniel J. Scholfield, Judith G. Hallfrisch, Helena G.M.. Consumption of Both Resistant Starch and $\beta$-Glukan Improves Postprandial Plasma Glucose and Insulin in Women. Diabetes Care 29:976-981, 2006

18. Annelisse Aigster. Physicochemical and Sensory Properties Of Resistant Starch-Based Cereal Products and Effects on Postprandial Glycemic and Oxidative Stress Responses in Hispanic Women. (Dissertation) The Faculty of The Virginia Polytechnic Institute. Blacksburg, Virginia. 2009

19. M. Frei, P. Siddhuraju, K. Becker. Studies on the in vitro starch digestibility and the glycemic index of six different indigenous rice cultivars from the Philippines. Food Chemistry 83 (2003) 395-402

20. Seghieri G, Tesi F, Anichini R, De Bellis A, Fabbri G, Malagoli R, Franconi F. Gender modulates the relationship between body weight and plasma glucose in overweight or obese subjects. Diabetes Res Clin Pract. 2008 Apr;80(1):134-8. Epub 2008 Feb 20.

21. John M. DeMan. Kimia Makanan. Diterjemahkan oleh Kosasih Padmawinata. Penerbit ITB, Bandung, 1997

22. Februadi Bastian. Teknologi Pati dan Gula. Hibah Penulisan. Buku Ajar Bagi Tenaga Akademik. Program Studi Ilmu dan Teknologi Pangan, Fakultas Pertanian, Universitas Hasanuddin, 2011

23. Elinor Hallstro, Francesco Sestili, Domenico Lafiandra, Inger Bjo, Elin O. stman. A novel wheat variety with elevated content of amylose increases resistant starch formation and may beneficially influence glycaemia in healthy subjects. Citation: Food \& Nutrition Research 2011. 557074

24. Leni Herliani A. Teknologi Pengawetan Pangan. Bandung : Alfabeta, 2013

25. Ade Irma Suriani. Mempelajari Pengaruh Pemanasan dan Pendinginan Berulang terhadap Karakteristik Sifat Fisik dan Fungsional Pati Garut (Marantha arundinacea) Termodifikasi. (Skripsi) Fakultas Teknologi Pertanian. Institut Pertanian Bogor, 2008

26. Hsing-Hsien Cheng, Ming-Hoang Lai. Fermentation of Resistant Rice Starch Produces Propionate Reducing Serum and Hepatic Cholesterol in Rats. The Journal of Nutrition. 2000; 0022-3166/00

27. M Denise Robertson, Alex S Bickerton, A Louise Dennis, Hubert Vidal. Insulin-sensitizing effects of dietary resistant starch and effects on skeletal muscle and adipose tissue metabolism. Am J Clin Nutr 2005;82:559-67 